\title{
KONSEP PENGOLAHAN DESAIN RUMAH TUMBUH
}

\author{
Nursyarif Agusniansyah ${ }^{1}, K$ urnia Widiastuti ${ }^{2}$ \\ ${ }^{1)}$ Dosen Prodi Arsitektur Fak. Teknik Universitas Lambung Mangkurat \\ ${ }^{2)}$ Dosen Prodi Arsitektur FT. Universitas PGRI Semarang
}

\section{ABSTRAK}

Rumah cenderung mengalami perkembangan dari desain awalnya. Hal ini terjadi karena beberapa alasan, seperti keterbatasan dana pada awal pembangunannya, dan kebutuhan ruangnya yang semakin bertambah. Renovasi kemudian menjadi sesuatu yang umum dilakukan disetiap rumah. Jika demikian maka diperlukan adanya suatu konsep yang memberikan solusi dalam pengembangan rumah yang efektif.

Tantangan terbesar pengembangan rumah adalah pada keterbatasan lahan dan anggaran untuk membangunnya. Konsep rumah tumbuh merupakan alternatif pemecahan dalam desain rumah yang berkembang. Konsep pengolahan desain rumah tumbuh ini dapat menjadi panduan dalam memilih atau membangun rumah bagi masyarakat.

Rumah Tumbuh berdasarkan arah perkembangannya dibagi menjadi rumah tumbuh horizontal dan rumah tumbuh vertikal. Jika lahannya luas, maka memungkinkan untuk pengembangan horisontal. Namun jika lahan terbatas, maka harus dilakukan pengembangan vertikal. Berdasarkan tahapan pengembangannya, perencanaan rumah tumbuh dapat dilakukan dengan mendesain denah ruang yang diperlukan secara keseluruhan, disertai dengan perencanaan tahap pembangunannya.

Kata Kunci:Desain rumah, Rumah Tumbuh, Pengembangan rumah

\section{PENDAHULUAN}

Rumah merupakan kebutuhan primer bagi manusia. Manusia berupaya memenuhi kebutuhan akan rumah ini dengan bererapa cara, seperti membeli rumah yang sudah jadi atau membangun rumahnya sendiri. Harga jual atau anggaran pembangunan menjadi faktor yang menjadi dipertimbangkan dalam memiliki rumah. Sebagian besar masyarakat memilih rumah yang tipenya kecil terlebih dahulu sesuai dengan kemampuan keuangannya, untuk dilakukan renovasi kemudian.

Menurut Fahminnansih (2010), rata-rata rumah-rumah di perumahan telah mengalami renovasi, salah satu alasan utama renovasi rumah adalah karena kebutuhan ruang di rumah tinggal bertambah atau berubah, seiring dengan pertambahan jumlah anggota keluarga yang mengghuni rumah, atau ada perubahan pada fungsi rumah. Jadi rumah tinggal cenderung berubah desainnya dari desain semula.

Jika renovasi untuk pengembangan merupakan sesuatu yang umumnya dilakukan disetiap rumah, maka perlu adanya suatu konsep yang memberikan solusi pengembangan rumah yang efektif. Efektif dalam arti mudah dan murah. Tantangan lain dari pengembangan rumah adalah keterbatasan lahan. Lahan yang terbatas menyebabkan sulitnya mengembangkan desain rumah. Sehingga, jika memang menginginkan desain rumah yang bertahap, maka perlu dipikirkan bagaimana desain awal rumah yang dapat dihuni dengan baik, untuk kemudian dapat dilakukan penambahan ruang tanpa banyak perubahan pada desain awal rumah. Jika hal ini dapat dilakukan, maka waktu dan biaya dalam melakukan pengembangan dapat ditekan.

Konsep tentang pembangunan rumah bertahap ini dikenal juga dengan istilah rumah 
tumbuh. Rumah tumbuh pada awalnya dibangun dengan luasan kecil, yang kemudian dapat di kembangkan. Konsep rumah tumbuh ini sangat bermanfaat bagi berbagai pihak. Baik bagi masyarakat yang akan membangun rumahnya sendiri, atau developer yang menawarkan perumahan bagi masyarakat.

\section{Fungsi-Fungsi Ruang di Rumah Tinggal}

Rumah tinggal dibangun sebagai tempat yang dapat mewadahi penghuni dengan segala aktivitasnya. Pada dasarnya, aktivitas utama manusia adalah makan, tidur, dan MCK (mandi, cuci, kakus). Maka setidaknya rumah tinggal dapat memenuhi ketiga fungsi tersebut. Fungsifungsi ini menjadi aktivitas pokok sebuah rumah yang kemudian berkembang ke aktivitas lainnya sesuai dengan kebutuhan dan keinginan penghuni.

Berdasarkan fungsi dan sifat ruang, rumah tinggal dapat dibagi dalam 3 area (Surowiyono, 2002), yaitu Living area, Sleeping area dan Service area. Living area merupakan

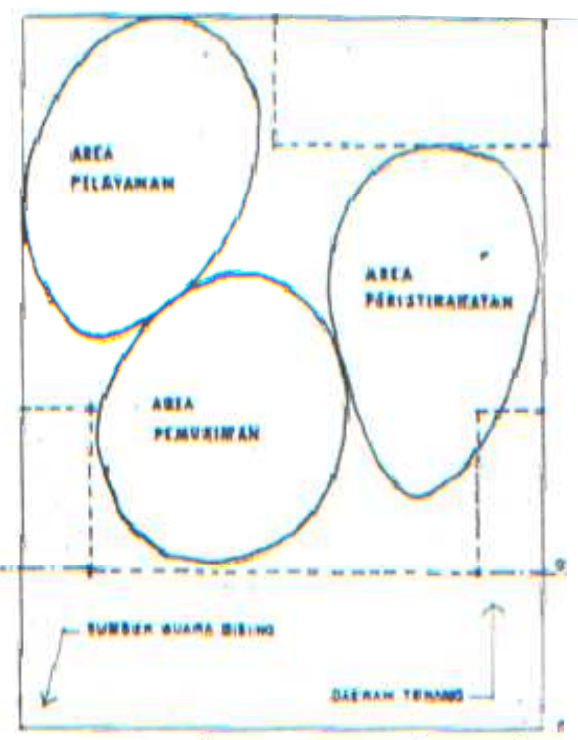

\section{Gambar 1. Pengelompokan ruang sejenis}

Sumber: Surowiyono, 2002

2. Pemilihan tata letak bangunan.

Tata letak bangunan disesuaikan dengan persyaratan ruang terhadap kondisi site. Misalkan ruang yang perlu ketenangan di

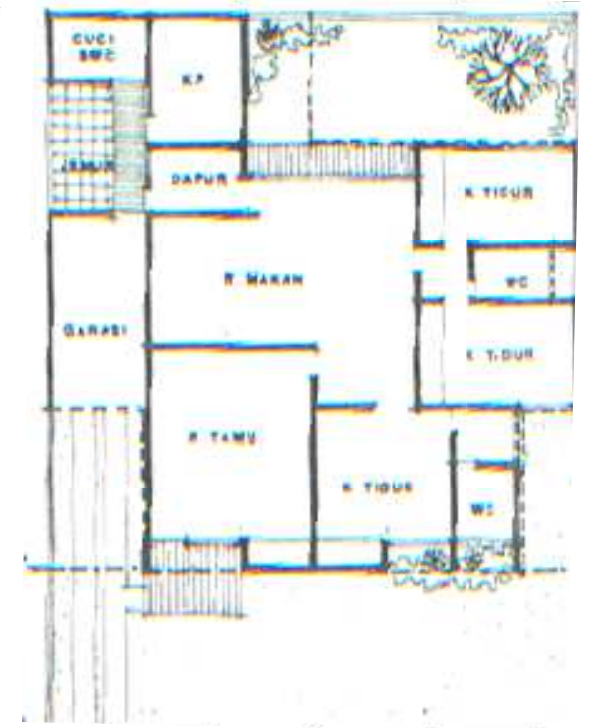

kumpulan ruang untuk kegiatan sehari-hari yang terdiri dari ruang tamu, ruang makan, ruang keluarga, ruang kerja. Sleeping area yang digunakan untuk beristirahat atau tidur. Biasanya terdiri dari kamar tidur dan ruangruang pendukung seperti $\mathrm{KM} / \mathrm{WC}$, dan ruang penyimpanan barang pribadi. Sedangkan service area merupakan area pelengkap dalam suatu rumah, terdiri dari dapur, gudang, dan garasi.

\section{Perencanaan Ruang di Rumah Tinggal}

Penyusunan ruang pada rumah tinggal dapat dilakukan dengan beberapa tahapan (Surowiyono, 2002), yaitu :

1. Pengelompokan ruang sejenis.

Ruang-ruang dikelompokkan sesuai dengan kelompoknya, apakah masuk kelompok area bermukim, beristirahat atau area pelayanan. Pengelompokan dimaksudkan untuk memperkirakan luas masing-masing area yang dibutuhkan, sehingga mudah pengaturannya pada site.

letakkan jauh dari lalu lintas jalan, kamar tidur memerlukan pencahayaan alami dan lain-lain. 


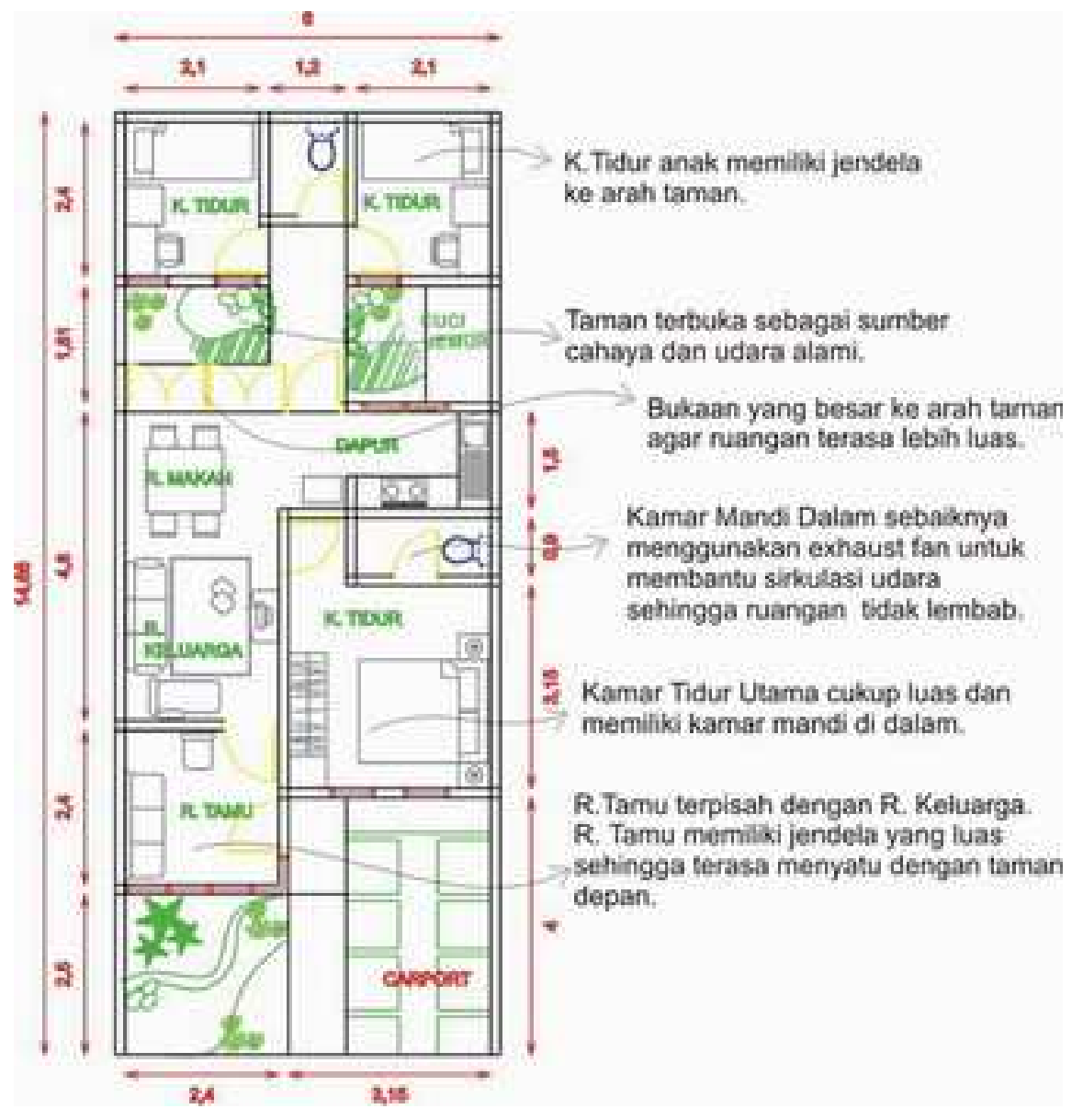

Gambar 2. Peletakan ruangan berdasarkan kondisi site

\section{Rumah Tumbuh Sebagai Solusi Pengembangan Rumah Tinggal}

Perubahan dan renovasi pada rumah tinggal sebaiknya dilakukan dengan konsep rumah tumbuh. Agusniansyah (2013) menyatakan bahwa rumah tumbuh dapat diartikan sebagai rumah yang dikembangkan dari ukuran rumah mungil menjadi luasan lebih besar. Membangun rumah dapat bertahap sesuai kemampuan keuangan demi menanggapi perkembangan kebutuhan ruangan dimasa sekarang dan ditambahkan ruang-ruang baru. Dengan konsep rumah tumbuh perombakan rumah diharapkan tanpa banyak membongkar fisik bangunan. Desain rumah lebih baik direncanakan sejak awal dengan beberapa tahapan. Pengembangannya pun dapat dilakukan secara horisontal maupun vertikal. Jika rumah tumbuh dari pengembangan rumah mungil yang dibeli baru direnovasi, akan lebih sulit ketimbang membangun dari awal dengan konsep rumah tumbuh.
Tahap renovasi yang banyak dilakukan adalah membongkar rumah awal. Akmal (2011) menyatakan bahwa pengembangan rumah dari tipe yang ditawarkan pengembang, mulai tipe 21 sampai tipe 68, dilakukan renovasi karena terdesak kebutuhan.

Rumah tumbuh dapat disiasati dari pengembangan rumah ukuran kecil. Wijaya (2006) memberikan gambaran bagaimana mengutak-utik desain rumah agar mampu menampung perkembangan kebutuhan ruangan dengan konsep rumah tumbuh ini. Dengan pengembangan rumah induk secara bertahap sesuai dengan kebutuhan dan faktor finansial, beberapa rumah yang ditawarkan oleh developerpun dapat dijadikan rumah induk yang hanya di desain secara umum dengan kebutuhan ruang seperti ruang tidur, ruang keluarga, dapur serta kamar mandi yang tersedia dalam desain rumah kecil. Pengembangan rumah induk berkonsep rumah tumbuh dilakukan dengan pertimbangan 
ketersediaan lahan dan persiapan konstruksi bangunan.

Zainal (1981) dalam Dewi (2007) mengatakan bahwa rumah tumbuh adalah suatu cara yang tepat dan ringan bagi mereka yang berpenghasilan kecil dan berminat membangun rumahnya sendiri secara berangsur-angsur atau bertahap. Dalam pemilihan rumah, masyarakat umumnya memilih desain rumah yang kecil. Dengan pemikiran bahwa pada saat tertentu, terutama ketika ketersediaan biaya mencukupi, akan dilakukan perbaikan.

Dewi (2007) menjelaskan bahwa rumah tinggal mengalami pertumbuhan dalam beberapa tahapan sebelum mencapai rumah yang diharapkan. Desain rumah awal minimal dapat mewadahi aktivitas dasar manusia dalam rumah. Dalam Pedoman Umum Rumah Sehat Sederhana (Kepmen Kimpraswil No. 403/KPTS/M/2002) dijelaskan bahwa aktivitas minimal yang perlu diwadahi sebuah rumah meliputi aktivitas tidur, makan, kerja, duduk, mandi, kakus, cuci dan masak serta ruang gerak lainnya. Dari hasil kajian, kebutuhan ruang per orang adalah $9 \mathrm{~m} 2$. Sehingga luasan rumah untuk 3 orang adalah $27 \mathrm{~m} 2$, dan luasan untuk 4 orang adalah $36 \mathrm{~m} 2$.

Tahapan mendesain rumah tumbuh dinyatakan oleh Agusniansyah (2014) berdasarkan konsep pelaksanaan pengembangannya secara bertahap untuk mengakodasi penambahan kebutuhan ruangan dan disesuaikan dengan keterbatasan anggaran dan luas ukuran lahan. Axellano (2011) memberikan tahapan merencanakan rumah tumbuh secara garis besar secara vertikal maupun horisontal dengan mempersiapkan konstruksi bangunan, fokus pada kebutuhan ruang, serta memastikan permasalahn finansial.

Berdasarkan penjelasan diatas, dalam perencanaan rumah tumbuh, desain awal rumah setidaknya memenuhi ukuran luas yang disyaratkan, dan mewadahi aktifitas minimal yang ditentukan. Pada tahap selanjutnya rumah dapat dikembangkan sesuai dengan persyaratan desain rumah tinggal.

\section{Perencanaan Rumah Tumbuh Berdasarkan Arah Pengembangan}

Berdasarkan arah pengembangan, perencanaan rumah tumbuh dibagi menjadi dua, yaitu rumah tumbuh horizontal dan rumah tumbuh vertikal. Rumah tumbuh horisontal adalah rumah yang berkembang ke arah samping, depan dan belakang, sehingga luasan rumah bertambah. Rumah yang tumbuh secara horisontal dapat dikembangkan apabila ada lahan kosong untuk dibangun bangunan tambahan.

Rumah tumbuh vertikal adalah rumah yang berkembang ke arah atas, menjadi rumah yang lebih dari 1 lantai, sehingga ketinggian bangunan bertambah. Perencanaan ini dilakukan jika lahan sangat terbatas untuk pengembangannya. Rumah tumbuh ini harus memiliki pondasi rumah yang kokoh, dan itu menjadi syarat mutlak bagi rumah tumbuh vertikal. Pondasi ini bisa dipersiapkan dengan perhitungan untuk bangunan tumbuh vertikal. Pada desain tipe ini, perencanaan desain dapat dilakukan dengan beberapa alternatif seperti:

a. Pada bangunan awal, strukturnya dipersiapkan untuk pengembangan lantai atas. Sehingga rumah dibangun 1 lantai dengan perhitungan struktur 2 lantai.

b. Rumah awal dibangun dengan struktur untuk 1 lantai, baru pada pembangunan berikutnya dilakukan perbaikan dan perkuatan struktur bawah bangunan seperti pondasi, sloof, kolom bangunan.

c. Desain rumah dibuat secara menyeluruh dan terpadu dengan rencana pengembangannya. Rumah awal di desain sebagai inti pada desain keseluruhan total, dan desain selanjutnya membungkus desain lama. 

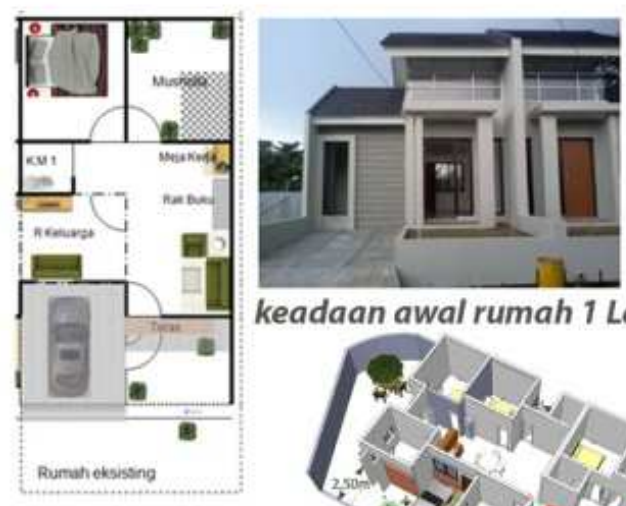

keadaan awal rumah 1 Lantai
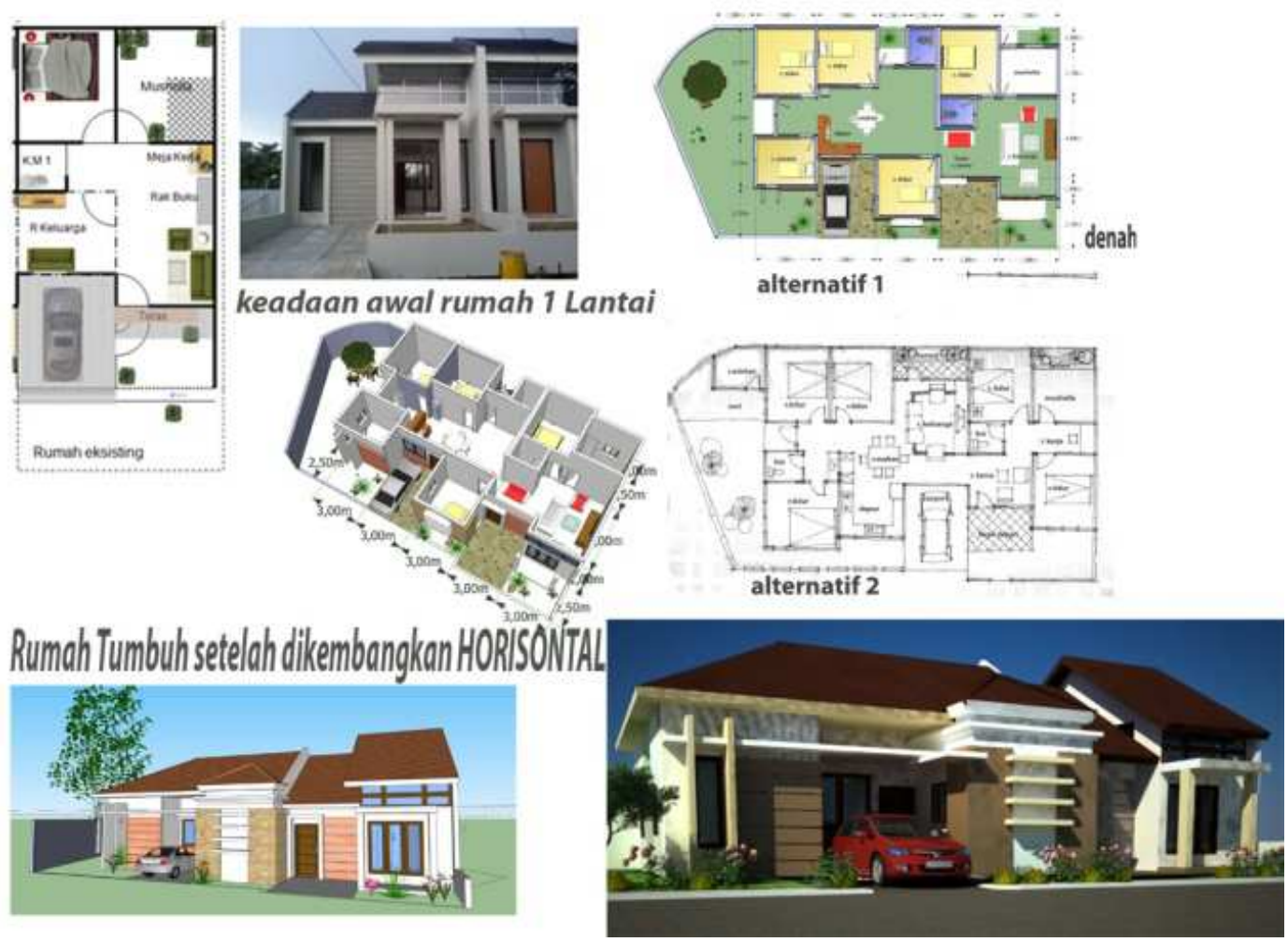

Gambar 3. Rumah Tumbuh Horisontal

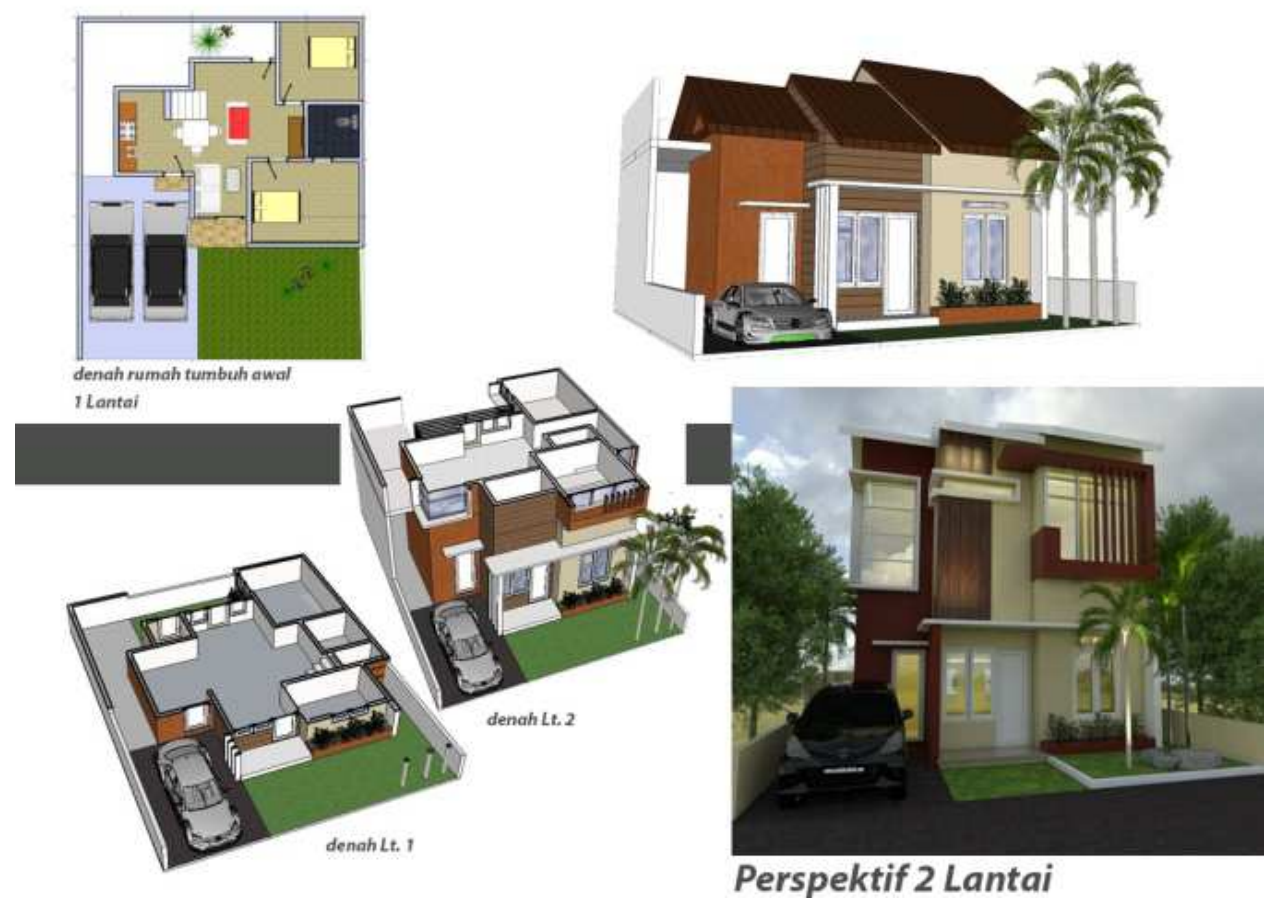

Gambar 4. Rumah Tumbuh Vertikal Alternatif 1 


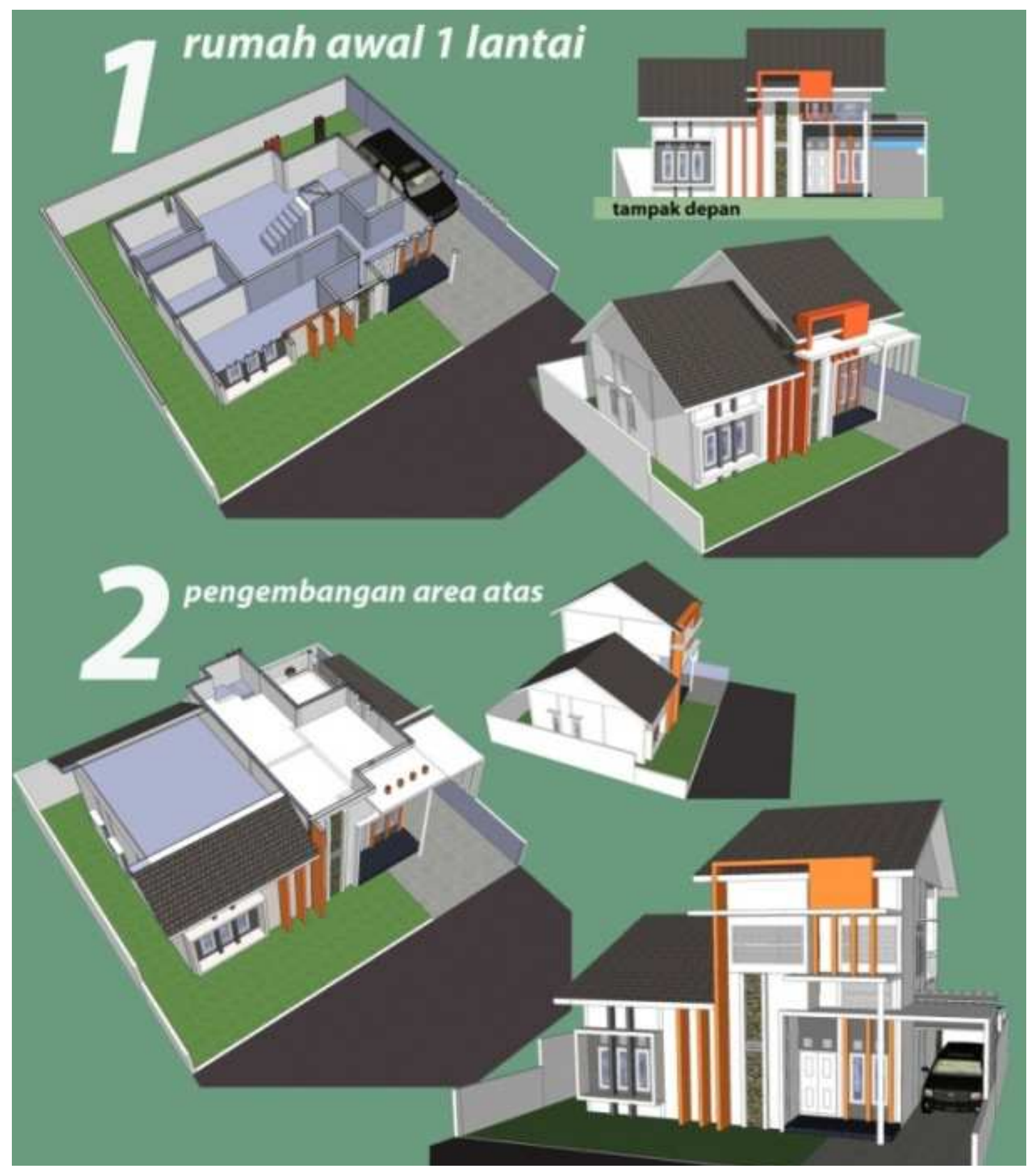

Gambar 5. Rumah Tumbuh Vertikal Alternatif 2 

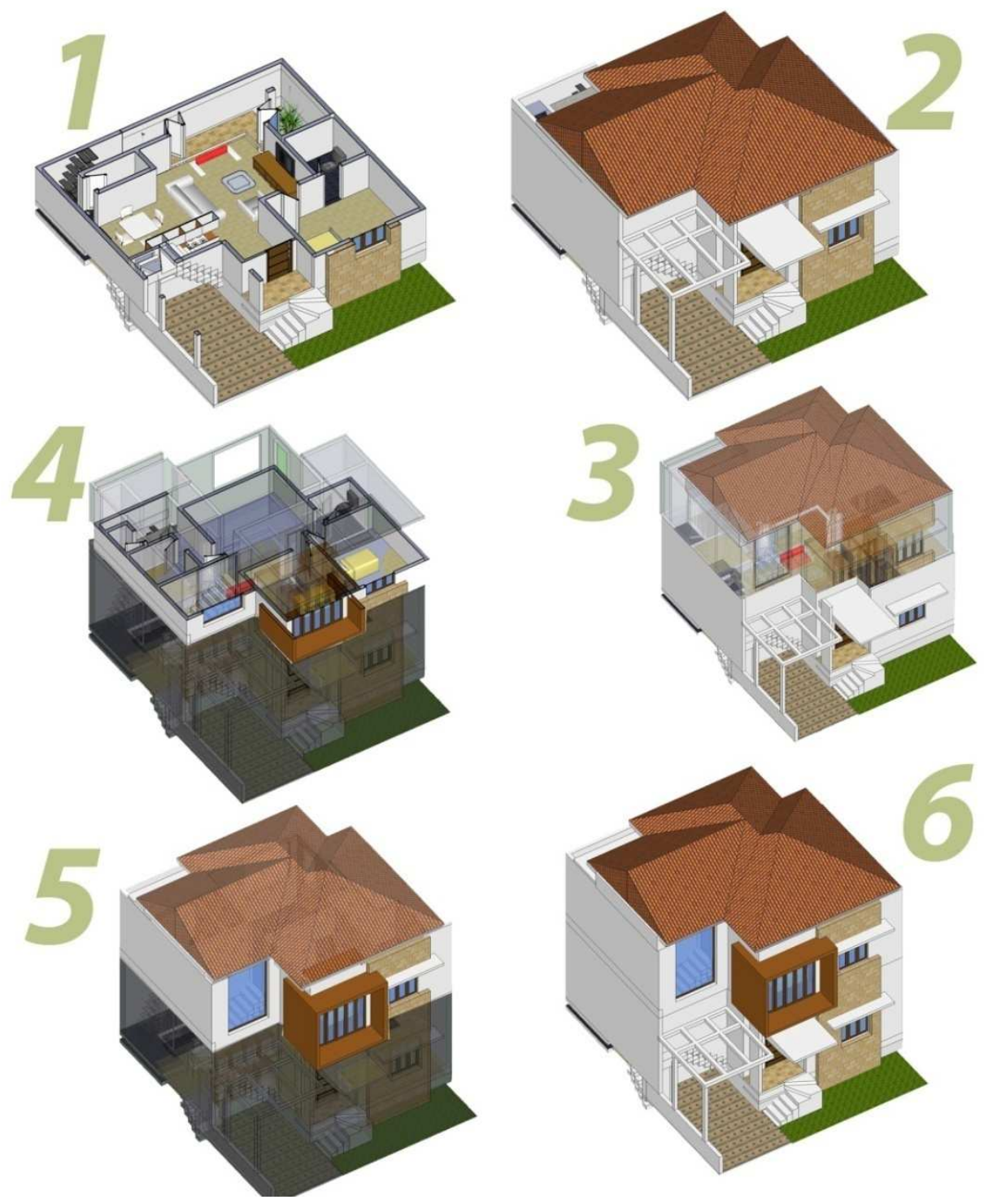

Gambar 6. Rumah Tumbuh Vertikal Alternatif 3

\section{Perencanaan Rumah Tumbuh Berdasarkan Tahapan Pembangunan}

Perencanaan rumah tumbuh berdasarkan tahapan pembangunannya dapat dilakukan dengan mendesain denah ruang yang diperlukan secara keseluruhan. Denah ini merupakan acuan dalam tahapan pembangunan atau pengembangan rumah. Desain tersebut sudah harus mempertimbangkan mana yang akan dibangun ditahap awal, dan bagian mana yang dibangun dalam pengembangan selanjutnya. Artinya, di masa depan, bisa dibangun tambahan ruang- ruang lain seperti ruang tidur, ruang keluarga, dan sebagainya tanpa harus melakukan banyak pembongkaran terhadap ruang-ruang yang sudah ada. Perlu diperhatikan juga, apakah rumah akan dikembangkan secara horizontal, atau vertikal. Bangunan rumah dapat dibangun satu lantai dulu, baru kemudian dikembangkan lagi dengan diperluas atau ditingkat.

Rumah awal umumnya berupa rumah kecil dengan ruang-ruang pokok, yang kemudian dikembangkan dengan ruang-ruang tambahan. Berikut ini adalah beberapa konsep rumah 

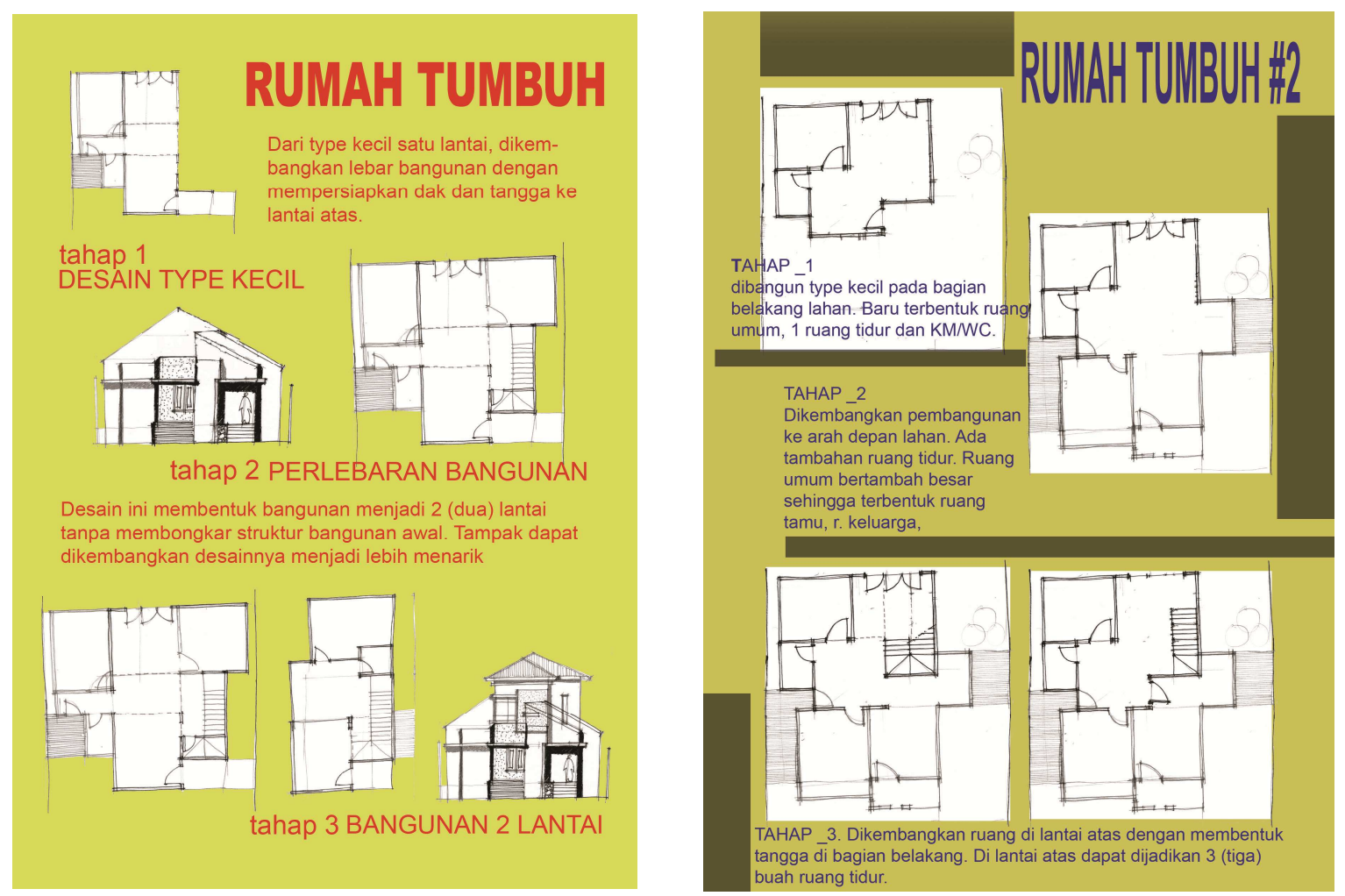

Gambar 7. Konsep Terpadu Desain Rumah Tumbuh Alternatif 1 dan 2

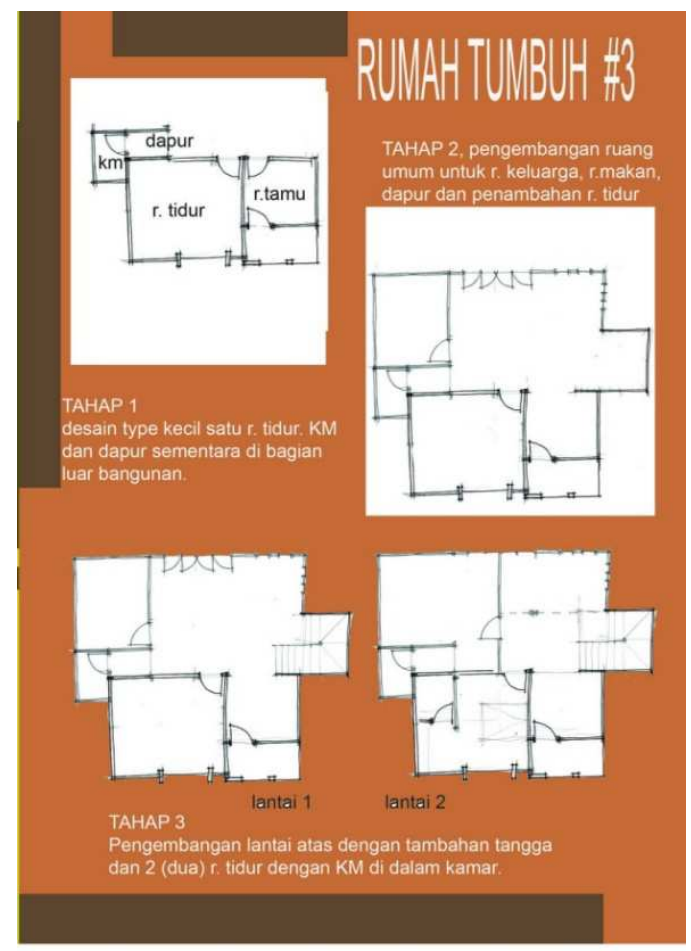

Gambar 8. Konsep Terpadu Desain Rumah Tumbuh Alternatif 3

Tahap-tahap pembangunan merupakan kunci utama untuk model rumah tumbuh. Perlu direncanakan mana yang dibangun pertama dan terakhir saat perluasan. Kebutuhan ruang yang didahulukan adalah ruang-ruang primer seperti ruang tamu, ruang keluarga, ruang tidur, kamar mandi dan dapur. 


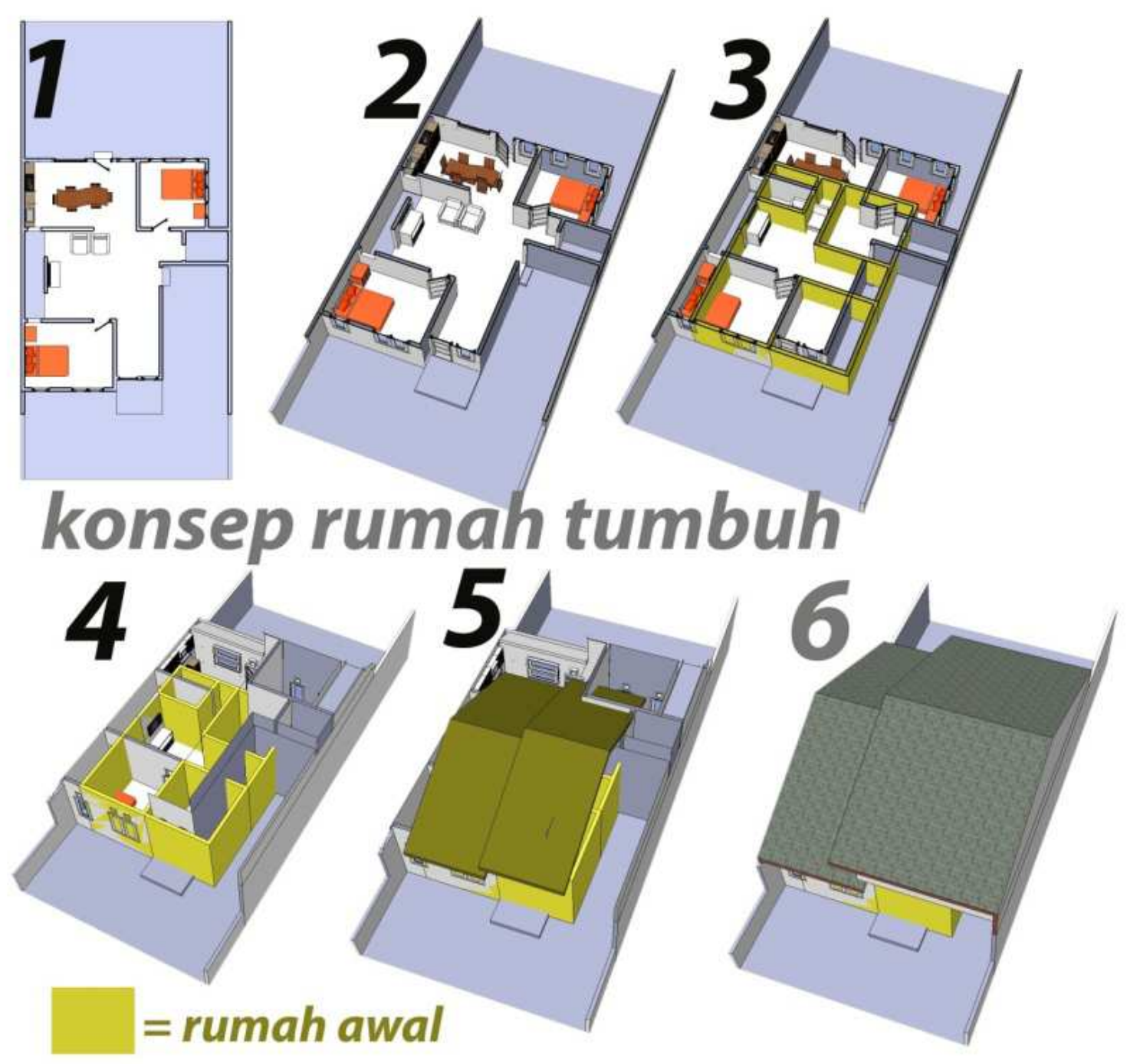

Gambar 9. Desain Awal Rumah dan Perkembangannya

Penataan ruang juga perlu dibuat sedemikian rupa, misalnya perencanaan letak tangga, letak toilet, letak taman, letak tandon air, dan sebagainya. Memang dalam hal ini faktor model rumah sangat menentukan pada awal pembangunan. Setelah rumah inti dibangun, maka selanjutnya pengembangan rumah dapat dilakukan. 


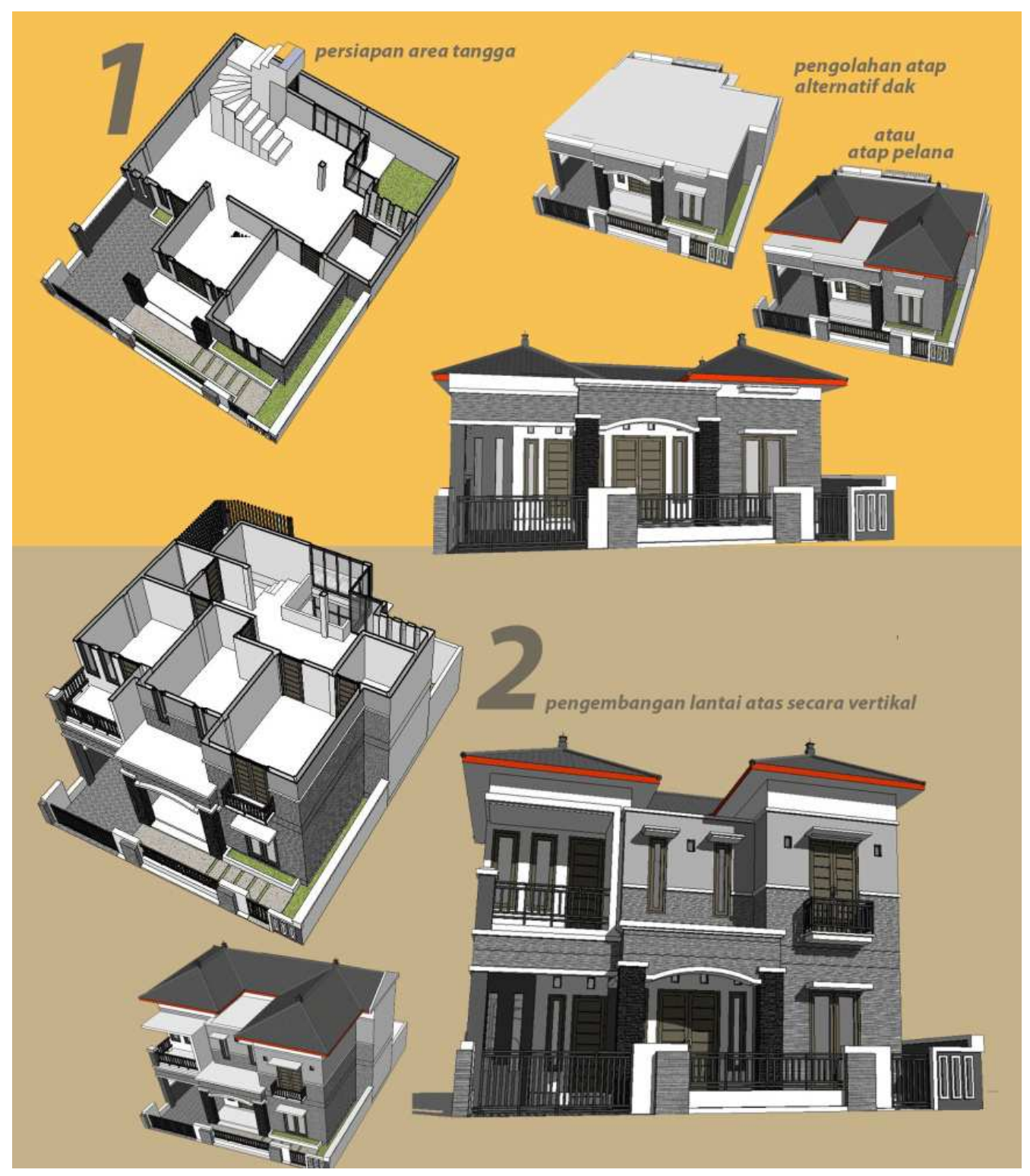

Gambar 10. Perencanaan Tata Ruang Pada Desain Rumah

\section{KESIMPULAN}

Dalam pembangunan rumah tumbuh ada beberapa hal yang harus diperhatikan, antara lain:

1. Penentuan besaran biaya yang akan digunakan.

2. Fokus pada kebutuhan ruang.

3. Tentukan pola pembangunan atau tahapan dalam pengerjaan, sehingga tidak perlu adanya pekerjaan bongkar pasang dalam kelanjutan pembangunan di tahap selanjutnya.

Berdasarkan arah pengembangan, rumah tumbuh terdiri atas rumah tumbuh horizontal dan rumah tumbuh vertikal. Rumah dapat dikembangkan secara horizontal jika lahannya masih tersedia. Pada desain tipe ini, struktur bangunan awal tidak banyak dan tidak perlu berubah. Rumah juga dapat dikembangkan secara vertikal Jika lahan terbatas. Pada desain tipe ini strukturnya harus dipersiapkan untuk pengembangan lantai atas.

Berdasarkan tahapan pembangunan, perencanaan rumah tumbuh dapat dilakukan dengan mendesain denah ruang yang diperlukan secara keseluruhan, disertai penentuan mana yang akan dibangun ditahap awal, dan bagian mana yang dibangun dalam pengembangan selanjutnya. 


\section{KEPUSTAKAAN}

Agusniansyah, N., 2013, Rumah Tumbuh : Desain Matang Pegang Peran (Wawancara dengan Hasto Prianggoro), Majalah Nova, Edisi 7-13 Oktober 2013, Jakarta.

Agusniansyah, N., 2014, Konsep Awal Rumah Tumbuh, http://www.rumahtumbuh.com/konsepawal-rumah-tumbuh. Diakses 25 September 2014.

Akmal, Imelda, 2011, Serial Ide: 20 Desain Inspiratif Rumah Tumbuh Tipe 45-68m2, PT. Gramedia Pustaka Utama, Jakarta.

Axellano, Georgio dkk., Menghitung Biaya Membangun Rumah Tumbuh Tipe 21, 30, 36, 45, PT. Kawan Pustaka, Jakarta

Dewi, NKA., Swanendri, NM., 2007, Rancangan Rumah Tumbuh Tipe KPR BTN Di Kota Denpasar, Proceeding PESAT (Psikologi,
Ekonomi, Sastra, Arsitektur dan Sipil),Univ. Gunadarma, Denpasar.

Fahminnansih, F., Indryani, R., Iriawan, N., 2010, Studi Penentuan Faktor-Faktor Pengaruh Tingkat Kecenderungan Renovasi Rumah Di Perumahan Dengan Menggunakan Analisis Survival, Proceeding Seminar Nasional Manajemen Teknologi XII Program Studi MMT-ITS, Surabaya

Kepmen Kimpraswil No. 403/KPTS/M/2002, tentang Pedoman Teknis Pembangunan Rumah Sederhana Sehat, Lampiran 1. Pedoman Umum Rumah Sederhana Sehat.

Surowiryo, T., 2002, Dasar Perencanaan Rumah Tinggal, Pustaka Sinar Harapan, Jakarta.

Wijaya, Franky., 2006, Opini: Cara Mensiasati Pengembangan Rumah Tumbuh, Majalah Estate, Edisi Vol. 3 No.27 Nopember 2006, Jakarta. 
